\title{
Nutritional Qualities and Shelf Life Extension of Gamma Irradiated Dried Pleurotus ostreatus (Jacq. Ex. Fr.) Kummer Preserved in Two Different Storage Packs
}

\author{
Nii Korley Kortei ${ }^{1, *}$, George Tawia Odamtten ${ }^{2}$, Mary Obodai $^{3}$, Michael Wiafe- Kwagyan ${ }^{2}$ \\ ${ }^{1}$ Department of Nutrition and Dietetics, School of Allied Health Sciences, University of Health and Allied Sciences, PMB 31, Ho, Ghana \\ ${ }^{2}$ Department of Plant and Environmental Biology, College of Basic and Applied Sciences, University of Ghana, Ghana \\ ${ }^{3}$ Food Microbiology Division, Food Research Institute Council for Scientific and Industrial Research, Accra
}

Copyright $\mathrm{O} 2017$ by authors, all rights reserved. Authors agree that this article remains permanently open access under the terms of the Creative Commons Attribution License 4.0 International License

\begin{abstract}
Pleurotus ostreatus has high nutritional value as an important source of protein, carbohydrates, vitamins, mineral elements and is among most favorite mushrooms of the world. Proximate composition and metabolizable energy of these mushrooms were evaluated for their dietary value. Fruit bodies were solar dried to a moisture content of $12 \%$ and exposed to low dose ionizing (gamma) radiations of 0 , $0.5,1,1.5$ and $2 \mathrm{kGy}$ at a dose rate of $1.7 \mathrm{kGy} / \mathrm{hr}$ and stored in polyethylene and polypropylene packs at room temperature $\left(28-30{ }^{\circ} \mathrm{C}\right)$ for a period of 12 months. Values ranged 14.11$15.80 \%, 6.16-8.31 \%, 0.65-1.24 \%, 13.56-15.39 \%, 12.51-$ $15.25 \%$, 61.16- $65.50 \%$ respectively for moisture, ash, fat, fibre, protein and carbohydrate. Metabolizable energy also ranged 247.8- $284.6 \mathrm{Kcal} / 100 \mathrm{~g}$ for 12 months storage. Although there were some significant $(\mathrm{p}<0.05)$ changes observed for some nutrients due to gamma irradiation and storage, the results obtained showed that the integrity of these nutrients in this mushroom were minimally affected as no adverse effects were observed.
\end{abstract}

Keywords Pleurotus ostreatus, Proximate, Nutritional, Metabolizable Energy, Gamma Irradiation

\section{Introduction}

Pleurotus ostreatus is a macrofungus which exploit polysaccharides (cellulose and hemicelluloses) usually from a wide range of lignocelluloses to produce expensive protein for human consumption [1]. Their global economic value is now inconceivable, and the reason for the rise in consumption is a combination of their value as food $[2,3]$ and their medicinal or nutraceutical properties [4-7].Their nutritive as well as medicinal attributes dates back to ancient times as early as $1500 \mathrm{BC}$ culled from ancient literatures.

Mushrooms are highly perishable and deteriorate within a short time after harvest due to its high moisture content and inability to maintain their physiological status.

In Ghana and most parts of the world, drying remains one of the best alternatives of preprocessing this mushroom. Drying of different species of mushrooms have been reported in previous studies [8-11]. It is one of the oldest means of food preservation and is applicable to a wide range of food products including P.ostreatus strain EM-1 [12] .The principle behind drying according to Labuza and Altunakar [13] is primarily reduction of moisture to levels low enough to inhibit microbial growth and also slow down enzymatic and other biological reactions that may contribute to food spoilage.

Food irradiation is the intentional exposure of food to ionizing radiation (such as gamma and electron beam) in order to enhance its shelf life without any detrimental effect on food quality as well as the safety of food. After decades of research, development, public debate and consumer acceptance trials in many countries, irradiation has emerged as a safe and viable technology for ensuring the safety and quality of food and for combating food-borne diseases. Indeed it is currently the best available technology according to IAEA, [14] as suitable for treating raw and partially raw food products and those countries which adopt it will benefit greatly in both domestic and international markets.

Perusal of pertinent literature revealed that scanty work had been done in this area of study. The objective of this study was to assess the effect of drying and gamma irradiation on the nutritional quality of mushroom (Pleurotus ostreatus) stored in polyethylene and polypropylene packs and stored over a period of 12 months.

\section{Material and Methods}

\subsection{Mushroom Samples}

Pleurotus ostreatus strain EM 1 were grown on 
composted sawdust as described by Kortei et al [15] and harvested at maturity from the cropping house of the Mycology Unit, Food Research Institute- Council for Scientific and Industrial Research, Accra, between the periods of February to May 2013.

\subsection{Processing}

\section{Drying of Mushroom Samples}

Drying was carried out by using a solar dryer at a temperature of $50-60^{\circ} \mathrm{C}$ to reduce moisture content to about $12 \%$ for an average period of 12 days.

Irradiation of Mushroom Materials

Fruitbodies were solar dried to a moisture content of $12 \%$ and exposed to low dose ionizing (gamma) radiations of 0 , $0.5,1,1.5$ and $2 \mathrm{kGy}$ at a dose rate of $1.7 \mathrm{kGy} / \mathrm{hr}$ in air from a Cobalt 60 source (SLL 515, Hungary) batch irradiator. Doses were confirmed using Fricke's dosimetry system which is a reference chemical dosimeter based on the chemical process of oxidation of ferrous ions $\left(\mathrm{Fe}^{2+}\right)$ in aqueous sulphuric acid solution to ferric ions by ionizing radiation at the Radiation Technology Centre of the Ghana Atomic Energy Commission, Accra, Ghana.

\section{Storage}

Forty (40) grams of dried oyster mushrooms (Pleurotus ostreatus) were packed and stored in polyethylene and polypropylene packs at room temperature $\left(28-30{ }^{\circ} \mathrm{C}\right)$ for a period of 12 months.

\section{Nutritional Analysis}

This study was carried out in the laboratories of Department of Food Science and Nutrition (University of Ghana) from March 2013 to March 2014.

\section{Determination of Moisture:}

The moisture content was determined by the gravimetric method of AOAC [16]. Two crucibles were each washed, dried, weighed and $2 \mathrm{~g}$ of fresh mushrooms weighed into each of the crucibles. The crucibles were placed in a thermostatically controlled oven (Gallenkamp oven 300 plus series, U.K) and the temperature maintained at $105^{\circ} \mathrm{C}$ for 5 hours, after which they were removed and placed in a dessicator to cool. They were then reweighed. The procedure was repeated until a constant weight was obtained. The moisture content was found by subtracting the final mass from the initial mass.

\section{Determination of Fat Content}

Procedure was carried out in accordance with AOAC [16] with modifications. Two grams of dried sample was transferred into a $22 \mathrm{~mm} \times 80 \mathrm{~mm}$ paper thimble and a small ball of cotton wool placed in the thimble to prevent loss of sample. A $250 \mathrm{ml}$ round bottom flask was washed and dried at $100{ }^{\circ} \mathrm{C}$ and weighed. Some anti- bumping granules were put into the flask. Fifteen millilitres $(15 \mathrm{ml})$ petroleum spirit of boiling point $60-80{ }^{\circ} \mathrm{C}$ was added. A quick fit condenser was connected to a Soxhlet extracter and refluxed for 4 hours at high heat using a heating mantle. The flask was removed and the solvent evaporated on a steam bath. The flask with its contents was put into a dessicator to cool to room temperature. It was then weighed and the mass of fat determined by subtraction.

\section{Determination of Ash Content}

Procedure was carried out in accordance with AOAC [16] with modifications. Two crucibles were each washed, dried and weighed and 2 grams of the whole mushrooms weighed into the crucibles. They were then placed in a muffle furnace, pre heated to $600{ }^{\circ} \mathrm{C}$ for 2 hours. The crucibles were then removed, allowed to cool in air, placed in a dessicator to cool completely and re-weighed. The masses of the crucibles and their contents were found by subtraction.

\section{Determination of Total Protein:}

According to a modified Buiret method by Burtis \& Ashwood [17]. Ten grams of ground mushroom was taken with $50 \mathrm{ml}$ of $1 \mathrm{~N} \mathrm{NaOH}$ and boiled for 30 minutes. The solution was cooled in room temperature and centrifuged at $1000 \times \mathrm{g}$ by a table centrifuge machine (Hardwarefactorystore.com, China). The supernatant was collected and total protein content was measured.

\section{Determination of Crude Fiber:}

The method outlined by AOAC [18] was used in this experiment. Half gram $(0.5 \mathrm{~g})$ of ground dehydrated mushroom was weighed (W1) and passed through a one milliliter $(1 \mathrm{~mm}$ ) mesh or screen into $600 \mathrm{ml}$ beaker (without spout). Fifty milliliters $(50 \mathrm{ml})$ cold (room temperature) NDS (the NDF solution) was placed in a beaker on a refluxing unit and allowed to boil. Heat was adjusted to even boiling, keeping the sample particles suspended. Heat was reduced as boiling began, to avoid foaming. It was refluxed for 60 minutes from onset of boiling. Gooch crucible was placed on the filter manifold and rinsed with hot water. The residue was filtered on to the crucible using light suction. It was washed twice with hot water. Mixture was allowed to stand for 5-10 minutes, washed twice with hot water, twice with acetone and dried using suction. For recovery reasons, acetone washing was done separately. The crucible was air dried for $10-15 \mathrm{~min}$ (some of the acetone will escape) and oven dry for 8 hours or overnight in a forced-air oven at $105^{\circ} \mathrm{C}$. It was cooled in a desiccator and weighed (W2) to obtain yield of cell wall. Crucible was ashed at $510^{\circ} \mathrm{C}$ for 3 hours, allowed to cool and removed from furnace, put in an oven (set at $105^{\circ} \mathrm{C}$ ) cooled and weighed (W3). The loss in weight was the ash free cell wall

$$
\begin{gathered}
\% \mathrm{NDF}=\frac{\mathrm{W}_{2}}{\% \mathrm{DM}}-\mathrm{W}_{0} \\
\% \mathrm{NDF}(\mathrm{DMB})=\frac{\% \mathrm{NDF}}{\% \mathrm{DM}} \times 100 \%
\end{gathered}
$$


$\mathrm{W}_{0}=$ Empty crucible weight.

$\mathrm{W}_{1}=$ Weight of ground sample

$\mathrm{W}_{2}=$ Weight of sample after cooling in dessicator

$\mathrm{W}_{3}=$ Weight of reweighed sample

\section{Determination of Total Carbohydrate}

According to Raghuramalu et al., [19] the content of the available carbohydrate was determined by the following equation [20] :

Carbohydrate $(\mathrm{g} / 100 \mathrm{~g}$ sample $)=[100-($ Moisture + Fat + Protein + Ash + Crude Fiber) $]$

\section{Determination of Metabolizable Energy Content:}

Fat, protein or carbohydrates can supply energy. Metabolizable energy was calculated as described by [16] using the following formula:

$\mathrm{ME}(\mathrm{Kcal} / 100 \mathrm{~g})=[(3.5 \mathrm{X} \mathrm{CP})+(8.5 \mathrm{X} \mathrm{CF})+(3.5 \mathrm{X} \mathrm{NFE})]$

Where, $\mathrm{ME}=$ Metabolic Energy; $\mathrm{CP}=\%$ Crude Protein; $\mathrm{CF}=\%$ Crude Fat; NFE $=\%$ Nitrogen Free Extract (carbohydrate)

\section{Results and Discussion}

\subsection{Nutritional Analysis}

The results of chemical (nutritional) analysis of gamma irradiated dried mushrooms stored in polythene and polypropylene packs are presented in Figures 1 and 2. The nutritional attributes of edible mushrooms are directly linked to their chemical composition. There is species variation in nutrients but it is dependent on type of substrate, stage of development, environmental conditions and essentially the post-harvest condition of storage [21, 22]. Likewise, the physical status of food (frozen or fresh, solid, liquid or powder) and also its composition influence the reactions induced by radiation [23].

Protein content for 0 month storage ranged from 12.51$15.25 \%$. Post irradiation storage studies revealed a decreasing trend of protein content which was however not significantly different $(p>0.05)$ irrespective of ionizing radiation dose and storage package used. After 12 months of storage, protein content ranged from 12.48 - 15.22\%. According to Mostafarvi [24], an interaction of ionizing irradiation and proteins could produce chemical reactions depending on the protein structure, state (native or denatured), physical status, amino acid composition, the presence of other substances and the radiation treatment. The most important changes include dissociation, aggregation, cross-linking and oxidation. Arvanitoyannis [23], indicated that low and medium doses induce only a small breakdown of food proteins into lower molecular weight protein parts and amino acids which cause less chemical reactions than steam heat interactions. Protein is an important constituent of dry matter of mushrooms $[25,26]$. The digestibility of mushroom protein can be as high as 72 to $83 \%$. Protein content of mushrooms depends on the composition of the substratum, size of pileus, harvest time and species of mushrooms [27]. The average protein content of cultivated edible mushrooms ranges from $3.5-4 \%$ of their fresh weight [28].

Protein content range obtained for P.ostreatus in this study, generally fell within the range (12.51- $15.25 \%)$ reported by several authors [28, 29, 30,31] who worked on Pleurotus spp. [32] Egwim et al., reported low protein content values for P. ostreatus $(14.03 \pm 0.01 \%)$ and also investigated some selected wild edible Nigerian mushrooms and recorded higher protein contents of range 26.25 $\pm 1.93-$ $60.38 \pm 0.20 \%$ for mushroom species Cantharella cibarius, Laccaria amethysta, Clitocybe odora, Lepista nuda, Macrolepiotata procera, Lepista saeva, Lactarius deliciousus, Laccaria laccata, and Hericium erinaceus. Al-Momany and Salih, [33] found values of 16.0- 16.8\% range for Pleurotus spp. amongst other edible fungi such as Agaricus macrosporus and Tricholoma saponaceum var squamosum. In terms of the amount of crude protein, mushrooms rank below animal meats but well above most other foods including milk [34]. On a dry weight basis, mushrooms normally contain 19 to $35 \%$ proteins compared to $7.3 \%$ in rice, $12.7 \%$ in wheat, $38.1 \%$ in soybean and $9.4 \%$ in corn $[35,27]$. A $100 \mathrm{~g}$ serving can provide about $12.5-15.1 \%$ of the recommended dietary allowance (RDA) or recommended nutrient intake (RNI). This high protein content implies that this fungus can contribute significantly to the daily human protein requirements, usually about $23-56 \mathrm{~g}[36,37]$.

Mushrooms contain high moisture depending on the mushroom species and other parameters related to harvest, growth, culinary and storage conditions [38]. Moisture content of dried P.ostreatus ranged from 14.11- 15.80\% for 0-3 month while 6-12 months storage ranged $14.11-16.11 \%$ and showed some significant differences $(p<0.05)$. This could be attributed to the difference in the extent of water hydrolysis by gamma radiation doses [23]. The moisture content of any food is an index of its water activity $[39,40]$, and is used as a measure of stability and susceptibility to microbial contamination [41, 42]. Dried mushrooms are not prone to rapid deterioration due to the absence of medium of transport of enzymes to facilitate chemical reactions which cause deterioration.

Although mushrooms are generally low in fat, they do contain essential unsaturated fatty acids and are also cholesterol free and as such considered essential and significant for human diet and health. Fat content ranged from $0.65-1.24 \%$ for $0-3$ month while that of $6-12$ months ranged $0.63-1.24 \%$. The average fat content of mushrooms is reported to be generally low, ranging from $0.6-3.2 \%$. Gamma radiation had a significant $(\mathrm{p}<0.05)$ effect on the fat content of dried mushrooms during storage. Radiation dose 2 kGy had an apparent significant $(\mathrm{p}<0.05)$ effect on the fat content. Free radicals formation during irradiation has been proven to increase lipid oxidation [43]. The range of fat 
content values obtained (0.65-1.24\%) were comparable to the $1.23 \%-0.53 \%$ reported by Musieba et al. [44] and Nurudeen et al. [45] respectively.

Crude fibre contents obtained in this present study ranged 13.56- $15.39 \%$ and its analysis showed some significant differences $(\mathrm{p}<0.05)$. Results obtained fell within range of results (3-32\%) reported by some researchers [44, 32]. On the average, a $100 \mathrm{~g}$ serving of mushrooms guarantees from 9 to $40 \%$ of the daily recommendation of dietary fibre [22]. Dietary fibre content was high (approx. $45 \%$ of dry matter). The fairly high level of fibre in the mushroom was a desirable characteristic since fibre plays an important role in human diet $[22,46,47]$, observed that glycogen and chitin form the major constituent of fibre content of mushrooms. Gordon [48] indicated that there is a "dietary fibre hypothesis" which suggests that fibre helps to prevent many diseases prevalent in affluent societies. Evidence from epidemiological studies suggest that increased fibre consumption may contribute to a reduction in the incidence of certain diseases like diabetes, coronary heart disease, colon cancer, high blood pressure, obesity, and various digestive disorders $[49,50,51]$. Dietary fibres alter the colonic environment in such a way as to protect against colorectal diseases. It provides protection by increasing faecal bulk, which dilutes the increased colonic bile acid concentrations which occur with a high-fat diet [52].

Carbohydrate values obtained in this study ranged from 61.39- $65.50 \%$ which represents the bulk of fruiting bodies accounting for on dry weight basis. Similar results have been reported by other researchers for cultivated Pleurotus mushroom [53, 20]. Pleurotus spp. dry matter usually include $50-60 \%$ carbohydrates composed of various compounds; monosaccharides, their derivatives and oligosaccharides (commonly called sugars) and both reserve and construction polysaccharides (glycans). Kalac [4], reported a decrease in mannitol and $\alpha$, trehalose which are the main constituents of oligosaccharides as well as polyols respectively. In general, irradiation modifies mono and polysaccharides, but thermal treatment can produce more modifications [54]. [55] reported carbohydrate values of Agaricus bisporus (56.47 $\pm 0.21 \%$ ) and Agaricus bitorquis $(39.94 \pm 0.17 \%)$. The amount of carbohydrates determined in Agaricus bitorquis was comparable to results obtained (61.39- 65.50\%) as average value for P.ostreatus in this present study. Carbohydrate that can be used by humans produces four calories per gram as opposed to nine calories per gram of fat and four per gram of protein. In areas of the world where nutrition is marginal, a high proportion (approximately $0.45-0.9 \mathrm{~kg}$ ) of an individual's daily energy requirement may be supplied by carbohydrate, with most of the remainder coming from a variety of fat sources [56].

Ash content values ranged between 6.16- 8.31\%. Statistical analysis revealed no significant $(\mathrm{p}>0.05)$ difference. Results obtained in these present studies were within range of values of 5.69- 7.82\% as reported by [57], [58] and [44] respectively. However, [32] recorded higher values of $20.55 \pm 0.13 \%$. By and large, packaging had no significant $(\mathrm{p}>0.05)$ effect on the proximate analyses.

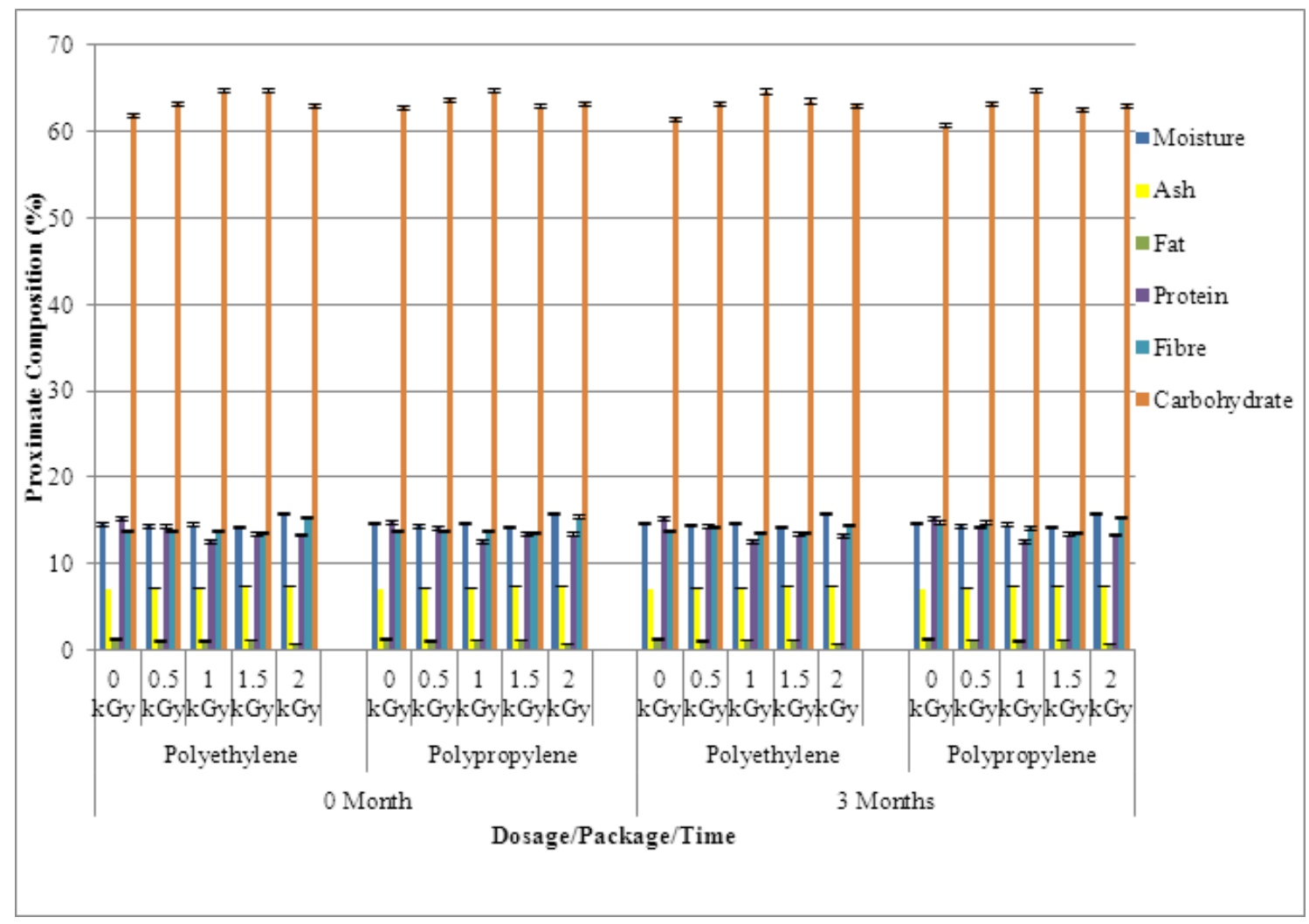

Figure 1. Effect of irradiation on proximate composition of dried mushrooms in storage packs during storage period of 0- 3 months 


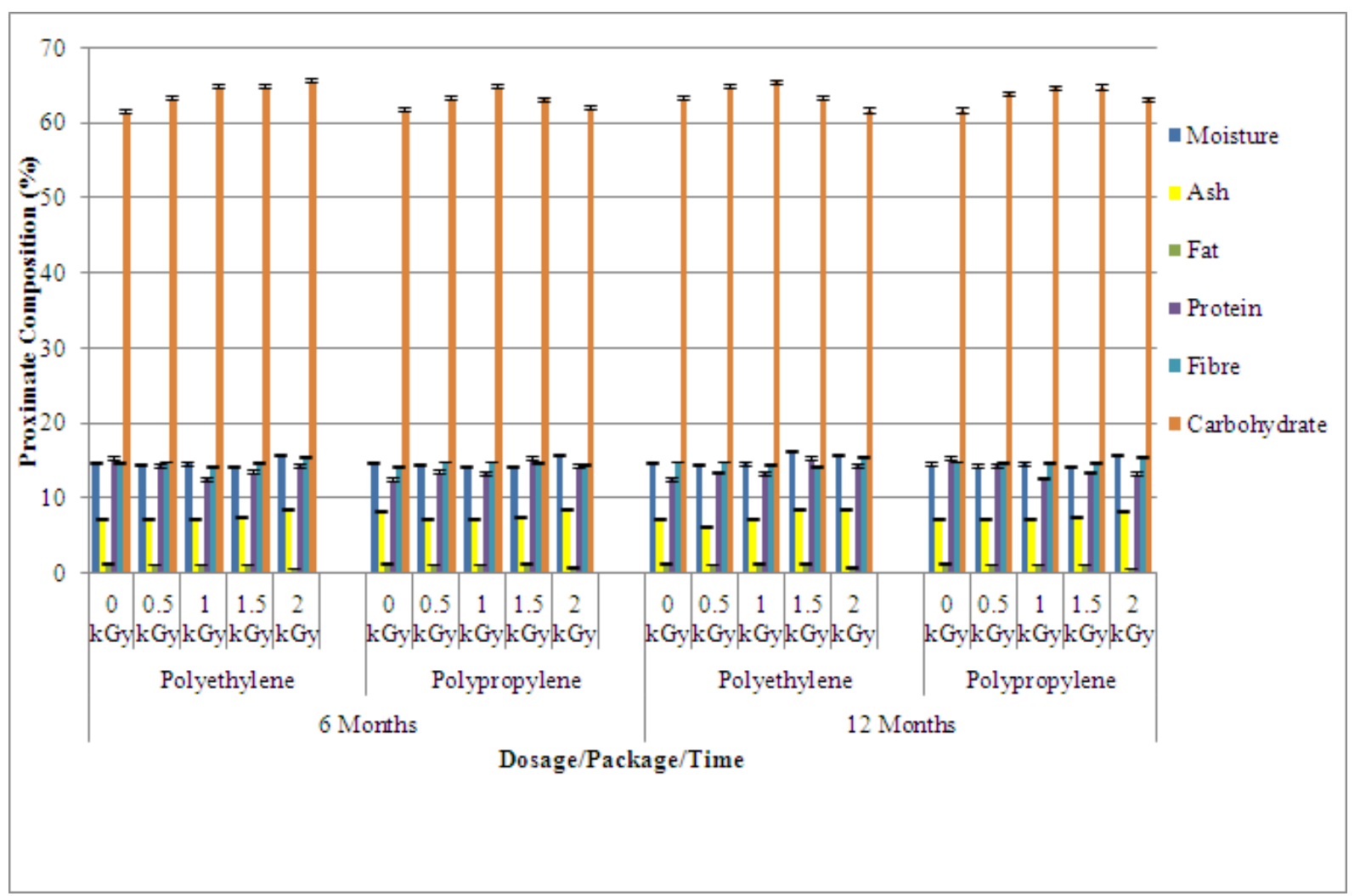

Figure 2. Effect of irradiation on proximate composition of dried mushrooms in storage packs during storage period of 6-12 months

\subsection{Metabolizable Energy}

Table 3. Effect of irradiation and storage on the Metabolic Energy (Kcal/100g) of Mushrooms

\begin{tabular}{c|c|c|c|c|c|c}
\hline $\begin{array}{c}\text { Storage } \\
\begin{array}{c}\text { Time } \\
\text { (month) }\end{array}\end{array}$ & $\begin{array}{c}\text { Package } \\
\text { material }\end{array}$ & \multicolumn{5}{|c}{ Applied Dose (kGy) } \\
\hline & & 0 & 0.5 & 1.0 & 1.5 & 2.0 \\
\hline \multirow{3}{*}{0} & P1 & $280.4^{\mathrm{b}}$ & $279.9^{\mathrm{b}}$ & $278.9^{\mathrm{b}}$ & $283.1^{\mathrm{c}}$ & $272.7^{\mathrm{a}}$ \\
\cline { 2 - 7 } & P2 & $279.9^{\mathrm{b}}$ & $280.8^{\mathrm{b}}$ & $279.7^{\mathrm{b}}$ & $276.5^{\mathrm{bc}}$ & $273.1^{\mathrm{a}}$ \\
\hline \multirow{3}{*}{3} & P1 & $273.7^{\mathrm{a}}$ & $279.3^{\mathrm{b}}$ & $282.1 \mathrm{~b}^{\mathrm{c}}$ & $279.5^{\mathrm{c}}$ & $276.9^{\mathrm{c}}$ \\
\cline { 2 - 7 } & P2 & $274.4^{\mathrm{a}}$ & $282.6^{\mathrm{c}}$ & $284.6^{\mathrm{c}}$ & $275.3^{\mathrm{a}}$ & $279.9^{\mathrm{ab}}$ \\
\hline \multirow{3}{*}{6} & P1 & $278.6^{\mathrm{b}}$ & $281.7^{\mathrm{b}}$ & $247.8^{\mathrm{a}}$ & $282.9^{\mathrm{b}}$ & $283.7^{\mathrm{b}}$ \\
\cline { 2 - 7 } & P2 & $279.8^{\mathrm{b}}$ & $280.0^{\mathrm{b}}$ & $278.7^{\mathrm{b}}$ & $277.5^{\mathrm{b}}$ & $273.4^{\mathrm{b}}$ \\
\hline \multirow{3}{*}{12} & P1 & $280.0^{\mathrm{b}}$ & $279.9^{\mathrm{b}}$ & $280.0^{\mathrm{b}}$ & $284.9^{\mathrm{c}}$ & $273.3^{\mathrm{a}}$ \\
\cline { 2 - 7 } & P2 & $279.0^{\mathrm{b}}$ & $281.8^{\mathrm{b}}$ & $278.8^{\mathrm{b}}$ & $282.3^{\mathrm{c}}$ & $272.0^{\mathrm{a}}$ \\
\hline
\end{tabular}

Means with same letters in a row are not significantly $(\mathrm{P}>0.05)$ different P1- Polythene, P2- Polypropylene

Generally, energy values of dried and gamma irradiated mushrooms stored in the different packaging materials ranged 247.8- $284.9 \mathrm{Kcal} . / 100 \mathrm{~g}$ of dried mushrooms and are presented in Table 3. The initial energy values ranged 272.7-283.1 and 273.1- $280.0 \mathrm{Kcal} / 100 \mathrm{~g}$ for polythene and polypropylene respectively. There was no significant $(p>0.05)$ effect of storage packs on the metabolizable energy. In terms of effect of gamma radiation, dose $2 \mathrm{kGy}$ showed an apparent effect $(p<0.05)$ on fat content which affected the energy content indirectly since it constitutes an integral part of the energy equation. After 3 months, energy ranged from 273.7- 282.1 and 274.4- 284.6 Kcal./100g for polythene and polypropylene respectively. There were significant differences $(\mathrm{p}<0.05)$ in energy values obtained. Storage for 6 months, gave values ranging 247.8-283.7 and 273.4-280

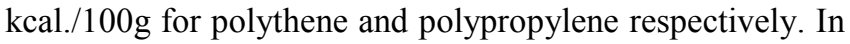
polythene package, irradiation caused significant difference $(p<0.05)$. However, polypropylene showed no significant difference $(\mathrm{p}>0.05)$ to irradiation effect. For storage for 12 month values, ranged from 273.3- 284.9 and 272.0- 282.3 Kcal./100g for both packages respectively. Energy values due to irradiation showed significant differences $(p<0.05)$ in both polythene and polypropylene.

[22] emphasized that owing to their high water content and low caloric value, mushrooms could be considered as a dietetic food suitable for low-calorie diets. In terms of energy values, the present results indicated that dry mushrooms stored up to 12 months were of good quality, low in calorie content and their energy value varied significantly $(\mathrm{P}<0.05)$. Obodai et al [58], [6] and [59], reported energy values within range of $272-389 \mathrm{Kcal} . / 100 \mathrm{~g}$ and $381-389 \mathrm{Kcal} . / 100 \mathrm{~g}$ respectively for Pleurotus spp. Mshandete and Cuff [60] reported energy values of $313 \mathrm{Kcal} / 100 \mathrm{~g}$ dry matter for Coprinus cinereus, $305 \mathrm{Kcal} / 100 \mathrm{~g}$ dry matter for Volvariella volvacea and $302 \mathrm{Kcal} / 100 \mathrm{~g}$ dry matter Pleurotus flabellatus. Egwim et al [32] obtained energy values of 305 $\mathrm{Kcal} / 100 \mathrm{~g}$ and $302 \mathrm{Kcal} / 100 \mathrm{~g}$ for Laccaria amethystea and Lepista nuda respectively. These values fall within what was recorded in the dry mushroom samples stored in both packaging materials before and after irradiation. Recently, 
[57] also found energy value of P.ostreatus on differently formulated rice straw composts to vary from 305.81- 387.80 Kcal./100g.

\section{Conclusions}

Our study showed that this mushroom species are good sources of proteins and carbohydrates. Several functional properties have also been detected as favourable, making it potentially useful in many food formulations. This research also demonstrates the ability of gamma irradiation to be used in the preservation of nutritional qualities of foods as changes that occurred due to gamma irradiation were minimal irrespective of the packaging material used in this experiment. Averagely, non-irradiated dried mushroom last not more than 6 months because of insect and pests damage. Additionally, gamma irradiation eliminated all these insects and pests to prolong its shelf life to 12 months. Gamma irradiation with its enormous attributes could be employed in food manufacturing industries to enhance product quality and shelf life.

\section{Acknowledgement}

We are grateful to Mrs Leonora Wontumi, Department of Nutrition and Food Science, University of Ghana and also to Messers S.N.Y. Annan, J.N.O. Armah, S.W.N.O Mills and SA Acquah of the Radiation Technology Centre, Ghana Atomic Energy Commision, Kwabenya, Accra, for undertaking the irradiation process.

\section{REFERENCES}

[1] Frimpong-Manso, J., Obodai, M., Dzomeku, M. and Apertorgbor, M. M. (2011). Influence of rice husk on biological efficiency and nutrient content of Pleurotus ostreatus (Jacq. Ex. Fr.) Kummer, International Food Research Journal, 18(1): 249-254.

[2] P. Kalac, P. (2009). Chemical composition and nutritional value of European species of wild growing mushrooms: A review. Food Chemistry 113: 9-16.

[3] Kortei, J. N. K. (2011). Growing Oyster Mushrooms (Pleurotus ostreatus) on Composted Agrowastes: An Efficient Way of Utilizing Lignocellulosic Materials, Lambert Academic Publishing, Saarbrucken, Germany.

[4] Kortei, N.K and Wiafe- Kwagyan, M. (2015). Comparative appraisal of the total phenolic content, flavonoids, free radical scavenging activity and nutritional qualities of Pleurotus ostreatus (EM-1) and Pleurotus eous (P- 31) cultivated on rice (Oryzae sativa) straw in Ghana. Journal of Advances in Biology and Biotechnology 3(4): 153- 164.

[5] Singh, V. K., Patel, Y. and Naraian, R. (2012). Medicinal properties of Pleurotus species (oyster mushroom): a review,
World Journal of Fungal and Plant Biology 3 (1): 1-12.

[6] Ferreira, I. C. F. R., Vaz, J. A., Vasconcelos, M. H. and Martins, A. (2010). Compounds from wild mushrooms with antitumor potential. Anti-Cancer Agents in Medicinal Chemistry 10 (5): 424-436.

[7] Kortei, N.K. (2015). Comparative effect of steam and gamma irradiation sterilization of sawdust compost on the yield, nutrient and shelf life of Pleurotus ostreatus (Jacq.ex. Fr) kummer stored in two different packaging materials. $P h D$ thesis, Graduate school of Nuclear and Allied Sciences, University of Ghana.

[8] Giri, S.K. and Prasad, S. (2007). Drying kinetics and rehydration characteristics of microwave-vacuum and convective hot-air dried mushrooms. Journal of Food Engineering 78: 512-521.

[9] Addo, A., Bart-Plange, A. and Boakye, D.M. (2009). Drying characteristics of cap and stem of mushroom. Journal of Science and Technology 29: 88-95.

[10] Wakchaure, G.C., Manikandan, K., Mani, I. and Shirur, M. (2010). Kinetics of thin layer drying of button mushroom. Journal of Agricultural Engineering 47: 41-46.

[11] Tulek, Y. (2011). Drying Kinetics of Oyster Mushroom (Pleurotus ostreatus) in a convective hot air dryer. Journal of Agriculture Science and Technology 13: 655-664.

[12] Kortei, N.K., Odamtten, G.T., Ayim Akonor, M., Akonor, P.T. (2016). Modeling the solar drying kinetics of gamma irradiation-pretreated oyster mushrooms (Pleurotus ostreatus). International Food Research Journal 23(1): 3439.

[13] Labuza, T.P. and Altunakar, B. (2007). Diffusion and sorption kinetics of water in foods. In G.V.Barbosa-Canovas, A.J. Fontana, S.J. Schmidt. and T.P. Labuza, (eds), Water activity in foods, Fundamental applications. Blackwell Publishing Ltd, Oxford, pp 215-238.

[14] I.A.E.A (International Atomic Energy Agency), (2009). Irradiation to ensure the safety and quality of prepared meals, Vienna, Austria, p. 375..

[15] Kortei, N.K, Odamtten G.T, Obodai M, Appiah V, Annan S.N.Y, Acquah S.A and Armah J.N.O. (2014). Comparative effect of gamma irradiated and steam sterilized composted 'wawa' (Triplochiton scleroxylon) sawdust on the growth and yield of Pleurotus ostreatus(Jacq. ex. Fr) Kummer. Innovative Romanian Food Biotechnology, 14: 69-78.

[16] AOAC. (1995). Official methods of analysis. Association of Official Analytical Chemists. Washington D.C.

[17] Burtis, C.A., Ashwood, E.R., Bruns, D.E. (2006). Textbook of Clinical Chemistry and Molecular Diagnostics, Elsevier Saunders, St. Louis.

[18] AOAC. Official Methods of Analysis, 16th edn. Gaithersburg, MD: AOAC international.1997.

[19] Raghuramulu, N., Madhavan, N.K., Kalyanasundaram. S. (2003). A Manual of Laboratory Techniques. National Institute of Nutrition. Indian Council of Medical Research, Hyderabad-500 007, India. pp: 56-58.

[20] Kortei, N.K. (2008). Determination of optimal growth and yield parameters of Pleurotus ostreatus grown on composted 
cassava peel based formulations. Msc.Thesis, Kwame Nkrumah University of Science and Technology, Kumasi, Ghana.

[21] Adejumo, T. O. and Awosanya, O. B. (2005). Proximate and mineral composition of four edible mushroom species from South Western Nigeria. African Journal of Biotechnology 4(10): 1084-1088.

[22] Manzi, I., Aguzzi, A., Pizzoferrato, L. (2001). Nutritional value of mushrooms widely consumed in Italy. Food Chemistry 73: 321-325.

[23] Arvanitoyannis, I.S. (2010). Irradiation of Food commodities: Techniques, Applications, Detection, Legislation, Safety and Consumer Opinion. Academic Press, London,United Kingdom.

[24] Mostafavi, H.A., Mirmajlessi, S.M. Mirjalili, S.M., Fathollahi, H., Askari, H. (2010). Gamma radiation effects on physico-chemical parameters of apple fruit during commercial post-harvest preservation. Radiation Physics and Chemistry 81: 666-671.

[25] Chang, S.T. and Buswell, J.A.(1996). Mushroom Nutriceuticals. World Journal of Microbiology and Biotechnology, 12: 473- 476.

[26] Alofe, F.V., Odeyemi, O., Oke, O.L. (1995). Three edible mushrooms from Nigeria: Their proximate and mineral composition. Plant Foods for Human Nutrition 49: 63-73.

[27] Bano, Z. and Rajarathanum, S. (1988). Pleurotus mushroom part II. Chemical composition nutritional value, post-harvest physiology, preservation and role as human food. Crit. Rev. Food Sci. Nutr., 27: 87-158

[28] Oyetayo, V.O. and Ariyo, O.O. (2013). Micro and macro nutrient properties of Pleurotus ostreatus (Jacq: Fries) cultivated on different wood substrates. Jordan Journal of Biological Sciences, 6(3): 223- 226.

[29] Wan- Rosli, W.I. and Aishah, M.S. (2013). Effect of different drying techniques on the nutritional values of oyster mushroom (Pleurotus sajor-caju). Sains Malaysiana 42(7): 937-941

[30] Khan, M.A., Amin, S.M.R., Uddin, M.N., Tania, M., Alam, N. (2008). Comparative study of the nutritional composition of oyster mushrooms cultivated in Bangladesh. Bangladesh $J$. Mushroom. 2(9): 9-14.

[31] Regula, J. and Siwulski, M.(2007). Dried shiitake (Lentinulla edodes) and oyster (Pleurotus ostreatus) mushrooms as a good source of nutrient. Acta Science Polish, Technology Alimentarius 6(4):135-142.

[32] Egwim, E.C., Elem, R.C., Egwuche, R.U. (2011). Proximate composition, phytochemical screening and antioxidant activity of selected wild edible Nigerian mushrooms. American Journal of Food and Nutrition 1(2): 89-94.

[33] Al-Momany, A.M. and Salih, G. (2011). Chemical compositions and nutritional value of three edible mushrooms widely consumed in Cyprus. Jordan Journal of Agricultural Sciences 7(3):541- 548.

[34] Chang, S.T. (1980). Mushroom as human food, BioScience 30: 399-401.

[35] Li, G.S.F. and Chang, S.T.(1982). Nutritive value of
Volvariella volvacea. In: Tropical Mushroom. Biological nature and cultivation methods. Ed. Chang,S.T. and Quimio, T. H. The Chinese University Press. Hong Kong.

[36] Chaney, S.G. (2006). Principles of Nutrition I: Macronutrients. In: Textbook of Biochemistry, with Clinical Correlation, 6th ed. Devlin, T.M. (ed.). John Wiley and Sons: New York, NY. p 14.

[37] FAO/WHO/UNU. (1991). Energy and Protein Requirements: Report of a Joint FAO/WHO/UNU Expert Consultation. WHO Technical Report Series 724. ISSN: 0512-3054. Http://www.fao.org/docrep/003/aa040e/AA040E01.htm

[38] Guillamón, E., García-Lafuente, A., Lozano, M., Arrigo, M. D., Rostagno, M.A., Villares, A., Martínez., J.A. (2010). Edible mushrooms: Role in the prevention of cardiovascular diseases. Fitoterapia, 81: 715-723.

[39] Olutiola, P.O., Famurewa,O., Sonntag, H.G.(1991). An Introduction to General Microbiology, A Practical Approach. Heidelberger Verlagsanstalt und Druckerei GmbH: Heidelberg, Germany.

[40] Labuza, T.P. and Altunakar, B. (2007). Diffusion and sorption kinetics of water in foods. In Barbosa-Canovas, G.V., Fontana, A.J., Schmidt, S.J. and Labuza, T.P. (Eds). Water activity in foods, Fundamental applications,. Oxford: Blackwell Publishing. p. 215-238.

[41] Uraih, N. and Izuagbe, Y.(1990). Public Health, Food and Industrial Microbiology. Uniben Press: Lagos, Nigeria.

[42] Kortei, N.K, Akonor, P.T., Appiah, A.H.K, Mills, S.W.O, Annan, S.N.Y, Armah, J.N.O and Acquah, S.A. (2015). Combined effect of solar drying and gamma radiation on the microbiological quality of P.ostreatus (Ex.Fr). Scentia Agriculturae 11(3): 132- 138.

[43] World Health Organization (WHO) (1994). Safety and nutritional adequacy of irradiated food. Geneva.

[44] Musieba, F., Okoth, S., Mibey, R.K., Wanjiku, S., Morsa, K. (2013). Proximate composition, amino acids and vitamins profile of Pleurotus citrinopileatus singer: An indigenous mushroom in Kenya. American Journal of Food technology 13: $1-7$.

[45] Nurudeen, T.A., Ekpo, E.N., Olasupo, O.O., Haastrup, N.O. (2013). Yield and Proximate Composition of oyster mushroom (Pleurotus sajor-caju) cultivated on different agricultural wastes. Science Journal of Biotechnology, Artcle iD sjbt $189,1-5$.

[46] Manzi, P. and Pizzoferrato, L. (2000). Beta-glucans in edible mushrooms. Food Chemistry 68(3): 315-318.

[47] Pizzoferrato, L., Manzi, P., Bertocchi, F., Fanelli, C., Rotilio, G., Paci, M. (2000). Solid- state C CP MAS NMR spectroscopy of mushrooms gives directly the radio between proteins and polysaccharides. J.Agric. Food Chem 48(11): 5484- 5488.

[48] Gordon, D.T. (2002). Intestinal health through dietary fiber, prebiotics, and probiotics. Food Technology 56: 23- 27.

[49] SACN (2008). Draft SACN Position Statement on Dietary Fibre \& Health and the Dietary Fibre Definition. SACN/08/20. $\mathrm{http}: / /$ www.sacn.gov.uk/pdfs/final draft sacnstatement on dietary_fibre_for_website.pdf Date $2 / 7 / \overline{13}$

[50] Eriyamremu, G.E. and Adamson, I. (1994). Early Changes in 
Energy Metabolism in Rats Exposed to an Acute Level of Deoxycholate and Fed a Nigerian-Like Diet. Annals of Nutrition and Metabolism 38: 174-183.

[51] FAO (1990). Roots, Tubers, Plantains, and Bananas in Human Nutrition. FAO Corporate Document Repository: Rome, Italy. http://www.fao.org/docrep/t0207e

[52] Dillard, C.J. and German, J.B. (2000). Phytochemicals: Nutraceuticals and Human Health. Journal of Science, Food and Agriculture 80(12):1744- 1756.

[53] Wani, B.A., Bhoda, R.H. and Wani, A.H. (2010). Nutritional and Medicinal importance of mushrooms. Journal of Medicinal Plants Research 4 (24): 2598-2604.

[54] Fan, X.T.(2005). Formation of furan from carbohydrates and ascorbic acid following exposure to ionizing radiation and thermal processing. J. Agri. and Food Chem., 53: 7826-7831.

[55] Sadiq, S., Bhatti, N. and Asif Hanif, M. (2008). Studies on chemical composition and nutritive evaluation of wild edible mushrooms. Journal of Chemistry and Chemical Engineering 27(3): 151-154

[56] Roffey, D.M. (2008). Exercise intensity, exercise training and energy metabolism in overweight and obese males. Ph.D thesis, Faculty of Health, Queensland University of Technology, Australia.

[57] Wiafe- Kwagyan, M.(2014). Comparative bioconversion of lignocellulosic rice wastes and its amendments by oyster mushrooms (Pleurotus ostreatus and Pleurotus eous) and the use of the spent compost as biofertilizer for the cultivation of tomatoes, pepper and cowpea. Ph.D thesis, University of Ghana.

[58] Obodai, M., Ferreira, I.C.F.R., Fenandes, A., Barros, L., Narh-Mensah, D.L., Dzomeku, M., Urben, A.F., Prempeh, J., Takli, R.K. (2014). Evaluation of the chemical and antioxidant properties of wild and cultivated mushrooms of Ghana. Molecules, 19: 19532-19548.

[59] Obodai, M.(1992). Comparative studies on the utilization of agricultural waste by some mushrooms (Pleurotus and Volvariella species). M.Phil. Thesis, University of Ghana, Legon.

[60] Mshandete, A.M. and Cuff, J. (2007). Proximate and nutrient composition of three types of indigenous edible wild mushrooms grown in Tanzania and their utilization prospects. Afr. J. Food, Agric, Nutrition and Development 7(6): 20-26. 